\title{
Strategy For Ecotourism Development In Efforts To Improve Community Welfare In Ayung River Flow (Case Study of Tukad Bindu, Kesiman Village, Denpasar City)
}

\author{
Luh Putu Kirana Pratiwi * and Ni Made Kencana Maharani \\ Agribusiness Study Program, Faculty of Agriculture, Mahasaraswati Denpasar, Bali, Indonesia \\ * kirana.pratiwi@unmas.ac.id
}

\begin{abstract}
Management of ecotourism-based tourism areas can create sustainable tourism. River revitalization in Denpasar City is one of the Denpasar City government work programs that aims to provide environmental education, environmental preservation and have economic potential in empowering the community's economy. The existence of rivers in Bali is still preserved to realize the implementation of Tri Hita Karana, which is maintaining good relations with God, nature, and humans so that the presence of water in Bali must be maintained in terms of quality and quantity. This study aims to explore the potential and development strategies of ecotourism to prosper the Ayung River flow in the city of Denpasar. Alternative strategies that need to be done to improve the welfare of the community are through intensive urban agriculture development, increasing agricultural productivity, tourism attractions, preserving the environment of the river, improving the quality of managers by empowering all stakeholders, and improving the community's economy with tourism activities that are carried out continuously. The government through related agencies is expected to facilitate consistently marketing access to agricultural products, tourism promotion through various major events of the Office to be held in Tukad Bindu so that economic improvement can be achieved significantly.
\end{abstract}

Keywords: Strategy, Ecotourism, Welfare, Watershed Communities.

\section{Introduction}

Tourism becomes the cornerstone of urban development policies that combine competitive supply under visitor expectations with a positive contribution to city development and the welfare of its population [1]. Ideally, the development of sustainable tourism is directed at developing urban ecotourism. Revitalization of the rivers in the city of Denpasar is one of the government's work programs aimed at providing ecological education for the surrounding community and economic value [2].

Along with tourists' awareness of the environment and issues about environmentally friendly development, giving the public a view on the importance of sustainable tourism. An optimal effort to utilize local resources is to develop tourism with the concept of ecotourism. Ecotourism is a tourist destination to enjoy and learn about nature, history, and culture, where the tourism patterns help the local economy and support the preservation of nature [3]. The principle of ecotourism has an inseparable part by minimizing the negative impact of the surrounding environment through conservation efforts by maintaining the quality of the local environment and culture and being able to empower the economy of the surrounding community [4].

The shift in the concept of tourism towards the ecotourism model is due to the saturation of tourists to visit artificial tourism objects. Therefore, this opportunity can be utilized maximally to attract foreign tourists visiting natural and cultural-based objects of the local population. Some key aspects in developing community-based ecotourism are: (1) The number of visitors is limited or arranged to fit the carrying capacity of the local community's environment and socio-culture. (2) Eco- 
friendly tourism patterns (conservation value). (3) Culture-friendly tourism patterns (educational and tourist value. (4) Helping the local economy directly (economic value). (5) The initial capital needed for infrastructure is not much (the value of community participation and the economy) [5].

The important strategy in the development of ecotourism in urban areas is the empowerment of the surrounding community in the tourist area [6]. Community empowerment is a vital unity related to physical, material, economic, and income aspects, institutional aspects (the growth of individual strength in the form of groups), the strength of cooperation, intellectual strength, and together to obey and apply the principles of empowerment. According to [7] that local community involvement is the main key in tourism development so that the concept of empowerment appears as an effort to provide local communities be free from voicelessness and powerlessness which includes four main indicators, namely: (1) the quality of human resources, (2) access to various information in their work, (3) accountability (responsibility for the preservation of local communities, and (4) the capacity of local organizations in fostering communities to be more empowered. The importance of community empowerment is to create independence to be able to act, understand and apply various development activities, in the future being able to improve the standard of living, community economic development, and welfare [8].

Revitalization of the rivers in the city of Denpasar is one of the government programs aimed at providing ecological education for the surrounding community and economic value. Traditionally, rivers are sacred areas that deserve to be preserved in carrying out Tri Hita Karana activities, namely maintaining good relations with God, nature, and people, so that the existence of water in Bali remains sustainable in quality and quantity [9]. In line with the 2016-2021 Denpasar City Planning Universe, namely: Denpasar's general development policies are prepared following sector development priorities as follows. First, strengthening cultural development which includes 4 dimensions: (a) culture as the basis for forming character, mentality, identity, and community identity; (b) Culture for developing arts and crafts products; (c) Culture as a basis for popular economic development, and (d) Culture as a basis for environmental preservation. Second, food is an effort to fulfill people's basic needs in the form of food independently (Denpasar Regional Development Planning Agency).

Tukad Bindu Kesiman, in East Denpasar District, is one of the river areas that has been able to be arranged by the Denpasar City Government and the local community. Tukad Bindu's arrangement also won a National award recently. The appeal and cleanliness arrangement made the Bandung Regency Environmental Service (DLH) attracted a visit to Tukad Bindu, Saturday (07/22). This visit was carried out to increase the Sabilulungan cadres to be carried out by Badung Regency. Tukad Bindu Foundation Advisor, Ida Bagus Alit B.A, said Tukad Bindu can be arranged and made a tourist attraction as an effort to foster a sense of love for the surrounding community, as well as community empowerment in the Kesiman region, Denpasar. Tida Not only focuses on the arrangement of the river flow, but this innovation also opens space for the involvement of the surrounding community to sell Balinese culinary around this tourist attraction.

Furthermore, according to him, the arrangement of Tukad Bindu was conducted from 2010 to 2012. To be handled by an official party, Tukad Bindu Foundation was formed on March 23, 2017 [10]. Thus, all sub-sectors related to education, environment, agriculture, and tourism must be optimized, so that they can become supporters and growth partners of sustainable tourism industries based on the development of community ecotourism in Denpasar City. The purpose of this research is to find out how much the potential for the development of sustainable ecotourism as a form of empowerment of urban local communities in the Ayung River Watershed namely Tukad Bindu, in Kesiman Village, East Denpasar District, Denpasar City. 


\section{Material and Methods}

This research was conducted along the Ayung River Basin namely Tukad Bindu in Kesiman Village, East Denpasar District, Denpasar City. The sample in this study was the local community along the Ayung River Basin. The method of determining respondents is by purposive sampling technique [11]. Methods of data collection through in-depth interviews with key informants such as Head of Kesiman Village, Head of the Tukad Bindu Foundation Manager, and local community leaders. Data collection methods are complemented by documentation and literature studies.

The analysis in this study included descriptive and research using the combined SWOT method. This research explores and analyzes the potential for the development of sustainable ecotourism as a form of empowerment of urban local communities in the Ayung River Watershed, Tukad Bindu, in Kesiman Village, East Denpasar District, Denpasar City.

External factors (EFE) and internal factors (IFE) in the development of sustainable ecotourism are analyzed SWOT analysis was carried out to determine the amount of empowerment of urban local communities in the Ayung River Basin, Tukad Bindu, carried out in several stages including:

Arranging internal factors (IFE) and external factors (EFE) in the development of ecotourism, then each factor is determined by weight and ranking.

1. Giving the weight of each factor starting from very important (1.0) to not important (0.0).

2. After the weights are determined then the rating is determined by influence. The rating value has a range of 1 to 5 . Rating 1 means not meaningful while rating 5 means very influential. 4 . The score is determined by multiplying the weight and rating. 5 . Then determine the total score of internal factors and external factors [12].

\section{Results and Discussion}

The results of internal and external environmental strategic factors that influence ecotourism development are used to compile an analysis of internal and external factors. Furthermore, an analysis using IFAS (Internal Strategic Factor Analysis Summary) and EFAS (External Factor Analysis Summary) matrices can analyze the potential for sustainable ecotourism development as the empowerment of urban local communities in the Ayung River Basin, namely Tukad Bindu, in Kesiman Village, District Denpasar Timur Denpasar City.

Strengths and weaknesses are part of the internal environment of ecotourism development that can increase the development of empowerment of farmers in urban areas. While the opportunity and threat factors are part of the external environment of ecotourism development that can spur the development of local community empowerment in urban areas.

\subsection{Internal Factors and Evaluation Strategy For Ecotourism Development In Efforts To Improve Community Welfare In Ayung River Flow}

Determination of internal factors for ecotourism development, determined through Focus Group Discussion (FGD). The internal factors chosen are the strengths and weaknesses that exist in the empowerment of local communities in urban areas. Focus Group Discussion (FGD) participants are people who are considered able to represent informant internal respondents, namely key informants in the Ayung River Basin, namely in Tukad Bindu in Kesiman Village. The internal factors used to construct the IFAS matrix can be seen as follows: 
The following strength factors.

a. An interesting tourist attraction, because this location is designated as a green belt to preserve the urban river environment, especially the Ayung River Basin, Tukad Bindu in Kesiman Village.

b. Easy accessibility, because the strategic tourist location is in the middle of the city, near the airport, in the Ngurah Rai bypass area, so that transportation is also easy.

c. Socio-cultural life is interesting because subak and members of the surrounding community still preserve the Hindu tradition based on the concept of Tri Hita Karana (a harmonious relationship between humans and God (Parhyangan), humans and other humans (pawongan), and humans with nature (palemahan). traditional ceremonies such as Nelu Bulanin, Nganten, Mesangih, Ngaben, etc.

d. Interesting artificial tourism potential, in the Tukad Bindu area there are tour packages: fishing tours, environmental education, water tourism, religious tourism, urban farming, etc.

e. The community is friendly and open along the tourist area to say hello, or buy local community food products, snacks, etc.

f. A clean and beautiful environment along the tourist area, because it is located along the Ayung River, namely Tukad Bindu in Kesiman Village with various other tourist rides.

g. Complete tourist support facilities, namely: jogging track area for jogging and cycling, semipermanent buildings for special food, water tourism, spiritual tourism, gazebo (a place to relax), etc.

The weakness factors are as follows.

a. The attraction of urban farming is less prominent.

b. Cultural attractions are less prominent: sculpture, because the main activity of tourism is artificial potential, namely: fishing, water tourism, spiritual tourism: yoga, relaxing to enjoy the scenery.

c. The lack of public knowledge about tourism potential causes the community to contribute less to the programs being carried out.

d. Promotion of tourism is lacking, because it only relies on acquaintance, or mouth to mouth. For online media, it has not been fully productive either, in partnership with government agencies, tour and travel, and hospitality, so the benefits that can be obtained each year are not too high.

e. Economic institutions are less productive because they do not have a Cooperative in tourism management.

Table 1

Internal Factor Evaluation Matrix for the Model of Strategy For Ecotourism Development In Efforts To Improve Community Welfare In Ayung River Flow

\begin{tabular}{clccc}
\hline Internal Strategic Factors & & & \\
\hline No & Strength & Weight & Rating & Score \\
\hline 1 & Interesting tourism object & 0.17 & 5 & 0.63 \\
2 & Easy accessibility & 0.15 & 5 & 0.59 \\
3 & Attractive social and cultural life & 0.11 & 4 & 0.25 \\
4 & Interesting artificial tourism potential & 0.16 & 5 & 0.54 \\
5 & Friendly and open society & 0.15 & 4 & 0.52 \\
6 & Clean and beautiful environment & 0.14 & 4 & 0.41 \\
7 & Complete tourism support facilities & 0.12 & 4 & 0.48 \\
\hline & TOTAL & 1,00 & 31 & 3.42 \\
\hline
\end{tabular}


Strategy for Ecotourism Development in Efforts to Improve Community Welfare in Ayung River Flow (Case Study of Tukad Bindu, Kesiman Village, Denpasar City)

\begin{tabular}{clccc}
\hline \hline Internal & Strategic Factors & & & \\
\hline No & Weakness & Weight & Rating & Score \\
\hline 1 & Less prominent agricultural attractions & 0.20 & 5 & 0.61 \\
2 & Less prominent cultural attractions & 0.22 & 5 & 0.59 \\
3 & Low public knowledge about tourism programs & 0.19 & 5 & 0.63 \\
4 & Promotion is not optimal & 0.17 & 4 & 0.68 \\
5 & Economic institutions that are less productive & 0.12 & 4 & 0.73 \\
\hline & TOTAL & 1.00 & 23 & 3.24 \\
\hline
\end{tabular}

Source: Primary data analysis

\section{External Factors and External Factors Evaluation of Urban Agriculture Development Strategies in Denpasar City}

Determination of the identification of external factors as a potential for the development of sustainable ecotourism as a form of empowerment of urban local communities in the Ayung River region is determined through a Focus Group Discussion (FGD). Focus Group Discussion participants are people who are considered to be able to represent external respondents, namely the Village Head, Head of the Food Crops Office, Horticulture, Denpasar City Plantations, and the Denpasar City Tourism Office. The selected external factors are strength and weakness factors, which are owned by the development of ecotourism in the empowerment of local communities in the Ayung River Basin in the City of Denpasar.

The external factors used to compile the EFAS matrix can be seen in the following opportunity factors. Opportunity Factors include the following.

a. The river environment in urban areas is sustainable because of the revitalization of rivers as areas that must be preserved in rivers that are already heavily polluted in urban areas.

b. Local culture as a tourist attraction, for example, sculpture, "Menyama Braya" activities, and farmers' religious rituals in the tourist area.

c. Tourist buildings that do not damage the environment, buildings must be built semi-permanently to protect the urban green belt area of agriculture.

d. The cleanliness and safety of the environment are maintained because of the principle of Palemahan in the Tri Hita Karana concept to maintain harmony with the surrounding nature.

e. Move the community's economic sector, because Tukad Bindu is an urban ecotourism area providing employment opportunities for the surrounding community.

f. The support of the city government in the preservation of urban green lines, by making jogging tracks in the Tukad Bindu area and semi-permanent buildings in the tourist area.

g. Increasing Local Revenue, because Tukad Bindu is one of the tourist locations that are often visited by urban communities.

The threat factors can be seen as follows:

a. The development of tourism in the future can damage the environmental sector if the waste generated by tourism is channeled to the river and visitors are not disciplined in the agricultural area. The erosion of cultural values if the tourism program does not have a cultural package offered continuously.

b. The environment is getting polluted, if when the event or tourism activity waste is not able to be managed properly.

c. The local community as an object of tourism is not directly involved in the tour program, so it needs to be educated and included as a working partner for tourism activities.

d. The marketing of agricultural products has not been fully involved in tourist areas, because it has not been created as a farm market activity or strategic area and as a promotional vehicle. 
e. The community is not fully involved in tourism activities due to a lack of education and active participation and communication between the two which is not yet transparent for managing tourism.

Table 2

The External Factor Evaluation Matrix of The Model of Strategy for Ecotourism Development in Efforts to Improve Community Welfare in Ayung River Flow

\begin{tabular}{clccc}
\hline & External Strategic Factors & & & \\
\hline No & Opportunities & 0.15 & 5 & 0.63 \\
1 & Agriculture in urban areas is sustainable & 0.11 & 5 & 0.33 \\
2 & Local culture as a tourist attraction & 0.13 & 4 & 0.40 \\
3 & Tourism buildings do not damage the environment & 0.16 & 4 & 0.39 \\
4 & The cleanliness and safety of the river environment are & & & \\
& maintained & 0.15 & 4 & 0.30 \\
5 & Moving the economic sector of the community & 0.17 & 4 & 0.57 \\
6 & Government support in preserving the green belt in urban & & & \\
& watersheds & 0.13 & 4 & 0.35 \\
\hline & Increase regional income & 1.00 & 30 & 2.97 \\
\hline
\end{tabular}

Table 3

The External Factor Evaluation Matrix of The Model of Strategy for Ecotourism Development in Efforts to Improve Community Welfare in Ayung River Flow

\begin{tabular}{clccc}
\hline External Strategic Factors & & & \\
\hline No & Threats & Weight & Rating & Score \\
\hline 1 & Development of tourism that is damaging to agriculture & 0.15 & 4 & 0.40 \\
2 & The erosion of cultural values & 0.12 & 4 & 0.29 \\
3 & The environment is getting polluted & 0.11 & 3 & 0.27 \\
4 & Local people only as objects of tourism & 0.16 & 4 & 0.51 \\
5 & Marketing of agricultural products is not yet complete & 0.17 & 4 & 0.53 \\
6 & The community is not fully involved in tourism management & 0.18 & 5 & 0.61 \\
7 & Other urban tourism competition & 0.11 & 4 & 0.21 \\
\hline & TOTAL & 1.00 & 29 & 2.82 \\
\hline
\end{tabular}

\subsection{Determination of Alternative Strategies with the SWOT Matrix}

The purpose of this stage is to produce viable alternative strategies. Not all strategies developed in the SWOT matrix are chosen for implementation. Four types of suggested strategies are SO (strength-opportunity) strategies, ST strategies (strength-threat), WO strategy (weaknessopportunity), and WT strategy (weakness-threat). The SWOT matrix in measuring the potential for sustainable ecotourism development as a form of empowering urban local communities in the Ayung River Watershed namely Tukad Bindu, in Kesiman Village, and formulating several alternative strategies, namely:

\section{Strategy S-O (Strengths-Opportunity)}

Strategies that use power to take advantage of opportunities are to conserve urban agriculture and educate the living environment along river basins through the development of ecotourism in increasing agricultural productivity, tourist attractions, preserving the environment, and increasing the economy of the community with tourism activities carried out.

2. Strategy S-T (Strengths-Threats)

The strategy of using power to overcome threats by empowering local communities through active participation in tourism management in Tukad Bindu, thereby increasing farmers' incomes.

3. Strategy W-O (Weaknesses-Opportunities) 
Strategies that minimize weaknesses by exploiting existing opportunities. The strategy used is to provide education and counseling through government agencies to local communities related to tourism programs that are run and increase the productivity of organic vegetables, use of rivers as water tourism and spiritual tourism, and education of the biological environment so that tourism promotion can be more effective and profitable.

4. Strategy W-T (Weaknesses-Treats)

The strategy to minimize weaknesses and anticipate threats in cooperation with the government and other private parties to increase tourism promotion and development of agricultural, cultural, environmental education attractions for the future sustainability of the program.

\section{Determination of Priority Strategies}

Based on the results of the questionnaire, the priority strategies are arranged that have the highest to lowest values, as shown in Table 4.

Table 4

Priority Strategy for Ecotourism Development in Efforts to Improve Community Welfare in Ayung River Flow

\begin{tabular}{clc}
\hline Priorities & Strategy & Value Weight \\
\hline I & Strength-Threat (ST) & 2.86 \\
II & Weakness-Opportunity (WO) & 2.32 \\
III & Weakness-Threat (WT) & 2.21 \\
IV & Strength-Opportunity (SO) & 1.83 \\
\hline
\end{tabular}

Source: Primary Data Analysis

The sequence of alternative strategies resulting from the IFAS-EFAS interaction in Table 5 shows an alternative strategy with the Strength-Threat (ST) strategy, in this case, the development of ecotourism potential is the first strategy that must be implemented. Then the second is the WeaknessOpportunity (WO) strategy, holding local community empowerment. The third strategy is WeaknessThreat (WT), which provides education and counseling. The fourth is Power-Opportunity (SO), which is establishing cooperation with the government and the private sector.

\section{Acknowledgments}

We would like to express our gratitude to all those who have played a role in the sustainability of research and produced scientific papers entitled Ecotourism Development Strategies in Efforts to Improve Community Welfare in the Ayung River River (Case Study of Tukad Bindu, Kesiman Village, Denpasar City) as a reference in sustainable urban preservation in the future. The author would like to thank Mahasaraswati University for its financial support. The author also thanks all informants involved in this research, namely Mr. Ir. Ida Bagus Wisnuardhana, M, Si as Head of the Bali Province Agriculture and Food Security Service, Gusti Ayu Made Suryani, SE., M.AP as Head of the Kesiman Urban Village, Denpasar City.

\section{Conclusion}

Based on research and discussion, it can be concluded that the alternative strategies used for the potential for the development of sustainable ecotourism as a form of empowering local urban communities in the Tukad Bindu area are as follows. 
1. Strategy S-O (Strengths-Opportunity)

Strategies that use power to take advantage of opportunities are to preserve urban agriculture and the river environment through the development of ecotourism in increasing agricultural productivity, tourist attractions, preserving the environment of the river, and improving the economy of the community with tourism activities carried out.

2. S-T Strategy (Strengths-Threats)

The strategy of using force to overcome threats by empowering local communities through active participation in tourism management in Tukad Bindu, thereby increasing the income of local communities in managing tourism.

3. W-O Strategy (Weaknesses-Opportunities)

Strategies that minimize weaknesses by exploiting existing opportunities. The strategy used is to provide education and counseling through the Denpasar City government service to farmers related to tourism programs that are run and increase the productivity of organic farming (urban farming), education of the biological environment so that tourism promotion is more effective and profitable.

4. W-T (Weaknesses-Treats) Strategy

The strategy to minimize weaknesses and anticipate threats is by collaborating with the government, other private parties to increase tourism promotion and development of urban agricultural attractions, culture, and environmental education in the sustainability of the program.

\section{References}

[1] Pujaastawa, I. B. G., Wirawan, I. G. P., \& Adhika, I. M. (2005). Pariwisata terpadu: Alternatif model pengembangan pariwisata Bali Tengah. (Alternative Tourism Development for Middle part of Bali). Denpasar: Udayana University Press.

[2] Kartasasmita, G, (2001). Pembangunan Untuk Rakyat: Memadukan Pertumbuhan dan Pemerataan. Pustaka Cidesindo Jakarta.

[3] Santoso, E. B., \& Widya, R. R. (2014). Gerakan pertanian perkotaan dalam mendukung kemandirian masyarakat di kota Surabaya. In Seminar Nasional Cities.

[4] Fandeli, C. (2000). Pengertian dan konsep dasar ekowisata. Yogyakarta, Fakultas Kehutanan UGM.

[5] Satria, D. (2009). Ecotourism Development Strategy Based on Local Economy in the Framework of Poverty Reduction Program in Malang Regency Area'. Journal of Indonesian Applied Economics, 3(1), 37-47.

[6] Hikmat, H. (2010). Strategi Pemberdayaan Masyarakat. Edisi Revisi. Humaniora Bandung (ID): Utama Press.

[7] Gde, P., Pitana, P., \& Gayatri, G. (2005). Sosiologi Pariwisata. Andi: Yogyakarta.

[8] Sharpley, R. (2000). Tourism and sustainable development: Exploring the theoretical divide. Journal of Sustainable Tourism, 8(1), 1-19.

[9] Suwantoro, G. (2019). Dasar-dasar pariwisata. Yoyakarta. Andi: Yogyakarta.

[10] https://bali.antaranews.com/berita/108820/sungai-bindu-denpasar-meraih-penghargaan-tingkat-nasional

[11] Sugiyono, S. (2010). Metode penelitian kuantitatif dan kualitatif dan $R \& D$. Bandung: Alfabeta.

[12] Rangkuti, F. (2002). Analisis SWOT teknik membedah kasus bisnis. Gramedia Pustaka Utama. 